\title{
Economic prospects of a rubber-cassava agroforestry in Nigeria
}

\author{
T.U. Esekhade*, S.O. Idoko, C.S. Mesike, C. Okwu-Abolo, S.O. Igberaese, S.O. Ighedosa \\ and L.A. Oghomieje
}

Rubber Research Institute of Nigeria, P.M.B. 1049

\begin{abstract}
A study to determine the financial benefits of intercropping immature rubber plantation with cassava in South Eastern Nigeria was carried out at the Rubber Research Institute of Nigeria, Iyanomo near Benin City. The study was set up in a randomized complete block design with each treatment replicated three times. Yield data generated were used to determine the profitability of the systems. The results showed economic yield from rubber as the rubber trees did not attain tappable girth throughout the duration of the study. a mean yield of about 25.72 tonnes of cassava tuber were generated from the sole cassava treatments for the four years period while a mean yield of about 22.92 tonnes of cassava tuber per hectare were generated from the cassava + rubber intercrop treatments in the same period. A total amount of 160,000 Naira was spent in four years as cost of intercropping. Total revenue generated from the sales of cassava in the rubber + cassava system was 900, 000.00 Naira per hectare with a Gross Margin and profit margin of 740,000 Naira and 673, 090.98 Naira respectively. A profitability index of the rubber + cassava system was 0.75 , indicating that, $75 \%$ of the total amount invested in the rubber + cassava system was recovered in the first four years compared to the additional costs incurred in the sole rubber plantation treatment. This study showed that intercropping cassava with rubber during the immature phase of rubber plantation guarantee early return on investment and more profitable compared with sole rubber plantation systems.
\end{abstract}

Keywords: Rubber, intercropping, sole, cassava, cropping systems, profitability, Nigeria.

\section{Introduction}

Rubber plantation enterprise requires a large expanse of land and almost $70 \%$ of the vast inter-row spaces are underutilized. Rubber has a long gestation period of rubber ( $5-7$ years), a period when no income accrue from the huge investment and the maintenance of the crop at this stage is so critical, hence the farmer need additional funds to weed the farm [9]. This situation has remained a disincentive to rubber farmers and has made rubber enterprise unattractive, especially to small-scaled farmers in Nigeria [6]. Hence, a timely adoption of appropriate plantation management practices that is capable of utilizing the under-utilized

\footnotetext{
* Corresponding author: esekhadutu@yahoo.com
} 
land resources and increases the revenue base of the enterprises is important to the attainment of the drive to increase rubber production in Nigeria.

Recently, intercropping of rubber with arable crops has been found to be beneficial to the growth of rubber and capable of improving the economy of the rubber enterprise thereby reducing the need for subsidies and credit to rubber farmers [19, 16, 6]. Cassava has been found to be one of the most promising among the arable crops evaluated in Nigeria $[6,5]$. Recently, intercropping of rubber with arable crops has been demonstrated to be beneficial to the growth of rubber plants and can thus improve the economy of the rubber enterprise [19, 6 and 5]. Rubber intercropping serves as additional sources of organic materials to the soil and help create a micro climate that leads to soil moisture conservation and subsequent encouragement of a more robust girth of young rubber saplings in the field [7]. [Esekhade $e t$ al., (1996), 9] demonstrated that intercropping of rubber with arable crops before the closure of the rubber canopy helps to reduce the cost of rubber plantation establishment by generating income to farmers during the immature phase of rubber trees. Cassava is a very important crop in Africa, with very high comparative production advantage over other crops (Facayode, et al., 2008). It requires less labour per unit output compared with other crops, making it a major crop attractive to resource poor farmers. It is Africa's second most important staple food, after maize, in terms of calories consumed. Cassava is a major source of calories for roughly two out of every five African's. It contributes more than 1,000 calories per person per day to the diet and many families eat cassava for breakfast, lunch, and dinner [13, 10, 11]. The intercropping of rubber with cassava has already been widely adopted by the smallscale farmers, but the practice is still not popular among the large-scale estate in Nigeria despite the potential benefits of the practice.

Therefore, this paper seeks to demonstrate clearly, the financial benefits of intercropping immature rubber with cassava plantation in Nigeria.

\section{Materials and Methods}

The experiment was conducted at the Rubber Research Institute of Nigeria, Iyanomo near Benin City located in the rainforest region of Southern Nigeria. Annual rainfalls during the two seasons of the experiment were $2352 \mathrm{~mm}$ and $2622 \mathrm{~mm}$. The area has a bimodal rainfall distribution. The temperature is high, with a mean of $29.0-32.1{ }^{\circ} \mathrm{C}$ and $25.7-31.4{ }^{\circ} \mathrm{C}$ in the first and second season respectively. Selected physicochemical properties of the soils before cropping shows that the $\mathrm{pH}$ of the area was 6.00 and 5.70 in $\mathrm{H}_{2} \mathrm{O}$ and $\mathrm{KCl}$ respectively, the organic carbon was $13.7 \mathrm{~g} \mathrm{~kg}^{-1}$, Total $\mathrm{N}$ was $2.4 \mathrm{~g} \mathrm{~kg}^{-1}$, available $\mathrm{P}$ was $4.77 \mathrm{mg} \mathrm{P} \mathrm{kg}^{-1}$. While the texture of the area was Loamy sand with a bulk density of $1.19 \mathrm{~g} \mathrm{~cm}^{3-1}$ and percentage moisture content of $12.2 \%$. The experimental area was first opened for cropping about 50 years ago and has been under long periods of fallow, after two years of cropping. The last fallow before the start of the experiment lasted for five years after it had been cropped to maize, yam, cocoyam, plantain and bananas for three years. The plantation was planted with GT I rubber clone and divided into sole rubber and rubber + cassava intercropping systems. The experimental plots were arranged in a randomized complete block design, with three replicates. Each plots measured $92.12 \mathrm{~m}^{2}$ excluding $1.0 \mathrm{~m}^{2}$ border to give a total area of 0.304 ha. The two rubber-based cropping systems were; Sole Rubber and Rubber + cassava. The cassava (Manihot esculentus Cranz cv 30572) were established in the inter-rows of rubber sapling at a spacing of $1.0 \times 1.0 \mathrm{~m}$, with at least $1.0 \mathrm{~m}$ away from the rubber saplings. Yield of the intercrops were determined at harvest. The samples of cassava harvested from each plot were oven dried to 12 percent moisture content at a temperature of $60^{\circ} \mathrm{C}$. The economic implications of the intercropping systems were determined after the sales of cassava. The local prices of cassava at the time of harvest were used in the computation of 
the economic viability of the farming systems. Rubber biomass was taken in place of latex yield because rubber trees had not reached tapping maturity.

The budgetary analysis technique emphasized the cost and returns to sole rubber and rubber + cassava production enterprise. The cost of establishing one hectare rubber plantation including all costs associated with land acquisition and farm implements form part of the fixed items. Depreciation on this equipment was calculated using the straight-line method with assumed salvage value of zero. The profit level and profitability ratios were calculated using gross margin and return to management [14].

The model specified in this study was as follows
1. GM
$=$ TR-TVC
2. NI
$=$ GM-TFC
3. Profitability Index or Return on sale
$=\mathrm{NI} / \mathrm{TR}$
4. The ratio of return on investment (\%RRI)
$=\mathrm{NI} / \mathrm{TR}$ X100
5. Rate of return on variable cost (\%RRVC)
$=\underline{\text { TR-TFC }} \times 100$

6. Operating Ratio

$=\mathrm{TVC} / \mathrm{TR}$

\author{
Where \\ $\mathrm{GM}=$ Gross Margin \\ $\mathrm{TR}=$ Total Revenue \\ TVC $=$ Total Variable Cost \\ NI $=$ Net Income \\ PI =Profitability Index \\ TFC $=$ Total Fixed Cost \\ $\mathrm{TC}=$ Total Cost
}

\title{
3 Results and discussion
}

\subsection{Yield of rubber and cassava}

The yield of rubber during the four years of the study was zero, because the rubber trees had not attained tappable maturity. However, the yields of cassava during the four years of the study are as presented in Table 2. The result showed that a mean yield of about 25.72 tonnes of cassava tuber were generated from the sole cassava treatments for the four years period while a mean yield of about 22.92 tonnes of cassava tuber were generated from the cassava + rubber intercrop treatments in the same period. The slight decrease in the yield of cassava in the rubber + cassava plots is attributed to competition between rubber and cassava. The competition is due to crop interactions in mixtures as the two crops have to struggle for the available below and above ground resources for their growth. This is consistent with the result of [5, 18, 1 and 17] they attributed the depression in growth and yields of crops in mixtures to competition for light, nutrients, and water.

Table 1. Agronomic Practice in Rubber + Cassava Intercropping System

\begin{tabular}{|l|l|}
\hline Agronomic Parameters & Adopted Agronomic Options for Rubber + Cassava \\
\hline $\begin{array}{l}\text { Age of rubber at } \\
\text { commencement } \\
\text { intercropping }\end{array}$ & $\begin{array}{l}\text { At planting to the } 4^{\text {th }} \text { year } \\
\text { of }\end{array}$ \\
\hline Cassava spacing & $1.0 \mathrm{~m} \mathrm{x} 1.0 \mathrm{~m}$ \\
\hline
\end{tabular}




\begin{tabular}{|l|l|}
\hline Plant population per hectare & 5000 plants \\
\hline Quantity of planting materials & 35 average sized bundles of 50 cassava stems \\
\hline Variety & 30555 and 30572 \\
\hline Time of planting & All the year round \\
\hline Weed control & $\begin{array}{l}\text { 2 hand weeding at } 4 \text { weeks after planting and } 8 \text { weeks } \\
\text { later; primextra, } 3.0 \mathrm{~kg} / \mathrm{ha} \text { (ai) applied post emergence } \\
\text { or Roundup at } 1.5 \mathrm{~kg} / \mathrm{ha} \text { (ai) applied in the avenues } \\
\text { before planting cassava. }\end{array}$ \\
\hline Fertilizer application & $\begin{array}{l}126.4 \mathrm{~kg} / \mathrm{ha} \mathrm{N} ; 28.2 \mathrm{~kg} / \mathrm{ha} \mathrm{P}_{2} \mathrm{O}_{5} ; \text { and } 146.8 \mathrm{~kg} / \mathrm{ha} \mathrm{K}_{2} \mathrm{O} \\
\text { applied in } 2 \text { split doses, at planting and } 16 \text { weeks after } \\
\text { planting. }\end{array}$ \\
\hline Expected yield & $3.5-20$ tonnes/ha \\
\hline
\end{tabular}

Table 2. Effect of Rubber Based intercropping on the yields of cassava

\begin{tabular}{|l|c|c|c|c|c|}
\hline \multirow{2}{*}{ Treatments } & \multicolumn{5}{c|}{ Yield (Tonnes/ha) } \\
\cline { 2 - 6 } & Year 1 & Year 2 & Year 3 & Year 4 & Mean \\
\hline Sole cassava & 21.19 & 42.80 & 19.44 & 19.44 & 25.7175 \\
\hline Cassava + rubber & 20.90 & 37.73 & 16.52 & 16.52 & 22.9175 \\
\hline LSD & NS & NS & NS & NS & \\
\hline
\end{tabular}

\subsection{Costs and returns analysis}

Table 3 shows the cost and returns to rubber and cassava production. The total revenue generated from the sales of cassava intercropped with immature rubber including the revenue accruable to the farmer from the sales of cassava stem during the four years period was N900, 000. A total of N25, 000.00 worth of cassava stem was needed for one hectare of farmland during a planting season. Therefore, 25,000 bundles of cassava stem multiplied by N300.00 (which is the lowest price of a bundle of cassava sticks) giving a profit of N75, 000.00. Hence, it can be concluded that farmers can make additional income from cassava stem. Indeed, a wise farmer will exploit all the money-making opportunities in cassava business and stop complaining of cassava glut in Nigeria. This was also reported by [9]. The total fixed and variable inputs costs amounted to N226, 457.7 to give a profit of N673, 090.98. This shows that intercropping cassava during the immature phase of rubber is profitable, this is consistent with the submission of [9, 6; Esekhade, et al., 1996; 2, 15]. The result of the profitability index of 0.75 in rubber + cassava intercropped system signals viability as this indicated that $75 \%$ of the total amount invested in the farm was recovered in four years when the plantation in intercropped with rubber. This result is in line with submission of [2], who reported high economic benefit of intercropping rubber with arable crops during the immaturity period of rubber. The total variable cost per hectare of the rubber + cassava intercropped accounted for $51.13 \%$ of the total cost, while the total fixed cost accounted for $48.87 \%$.

Table 3. Average Costs and Returns to the Rubber and Cassava production for a 4 years period at Iyanomo

\begin{tabular}{|l|l|r|}
\hline \multicolumn{3}{|c|}{ Revenue (Naira) } \\
\hline & Sole Rubber & \multicolumn{1}{|c|}{ Rubber + Cassava } \\
\hline Sales from Latex & 0 & 0 \\
\hline Sales of Cup Lump & 0 & 0 \\
\hline Sales from Tubers & 0 & $700,000.00$ \\
\hline Sales from Stems & 0 & $200,000.00$ \\
\hline
\end{tabular}




\begin{tabular}{|l|r|r|}
\hline \multicolumn{1}{|c|}{ Total Revenue (TR) } & $\mathbf{0}$ & $\mathbf{9 0 0 , 0 0 0 . 0 0}$ \\
\hline \multicolumn{1}{|c|}{ Variable Cost (Naira) } \\
\hline Fertilizer & $30,000.00$ & $60,000.00$ \\
\hline $\begin{array}{l}\text { Rubber Maintenance 2 x weeding/year } \\
\text { (20 M/days/ha/weeding @ }\end{array}$ & $40,000.00$ & 0,00 \\
N250/M/day) & & \\
\hline Labour for Cassava Establishment & 0.00 & $50,000.00$ \\
\hline $\begin{array}{l}\text { Intercrop Maintenance 2 x } \\
\text { weeding/year (20 } \\
\text { M/days/ha/weeding @ N250/M/day) }\end{array}$ & 0.00 & $50,000.00$ \\
\hline Total Variable Costs (TVC) & & \\
\hline \multicolumn{1}{|c|}{ Fixed Costs (Naira) } \\
\hline 1 ha rubber plantation + cost of Land & $65,514.29$ & $\mathbf{1 6 0 , 0 0 0 . 0 0}$ \\
\hline Cutlasses & 342.30 & $65,514.29$ \\
\hline Rain Coats & 456.40 & 342.30 \\
\hline Rain Boots & 453.40 & 456.40 \\
\hline Files & 142.63 & 453.40 \\
\hline Total Fixed Cost (TFC) & $\mathbf{6 6 , 9 0 9 . 0 2}$ & 142.63 \\
\hline Total Cost (TC) & $136,909.02$ & $\mathbf{6 6 , 9 0 9 . 0 2}$ \\
\hline Total Revenue & 0.00 & $226,909.02$ \\
\hline Gross Margin (GM) & $-70,000.00$ & $900,000.00$ \\
\hline Net Income (NI) & $-136,909.02$ & $740,000.00$ \\
\hline Profitability Index & & $673,090.98$ \\
\hline Rate of Return on Investment & & 0.75 \\
\hline Rate of Return on Variable Cost & & $44.79 \%$ \\
\hline Operating Ratio & & 420.68 \\
\hline
\end{tabular}

\section{Conclusion}

These results showed that intercropping rubber with cassava at immature phase of rubber trees is agronomically and economically more profitable compared with sole rubber plantation. Because intercropping rubber with cassava resulted in the production of food for farmers family, guarantees early return on investment and boost farmers livelihood compared with sole rubber systems. It is herby recommended that rubber farmers especially smallholders be encouraged to intercrop their immature plantation with food crops especially cassava to ensure early return on investment and boost the livelihood.

\section{References}

1. Abolaji, J.O. and F.J. Olsen. Nigerian Journal of Agronomy 3:104-107(1998).

2. Esekhade, T.U. and F.I. Ojiekpon. Indian Journal of Natural Rubber Research. 10, 1\&2:91-96(1997).

3. Esekhade, T.U., I.K. Ugwa, and E.O. Aigbekhaen. Indian Journal of Natural Rubber Research. 9,1:36-39(1996)..

4. Esekhade, T.U. I.K. Ugwa and F.I. Ojiekpon. Effects and economic viability of intercropping cooking banana at different spacing with Hevea saplings in Proc.Of the $5^{\text {th }}$ Annual Conference of the Nigerian Society of Biological Conservation, Umudike $6-10^{\text {th }}$ October (1996). 
5. Esekhade, T.U. and S.O. Idoko. Journal of Sustainable Tropical Agricultural Research. 31:33-40(2010).

6. Esekhade, T.U., I.K. Ugwa, J.R. Orimoloye and S.O. Idoko. Journal of Sustainable Agriculture. 22,4:79-94(2003).

7. Esekhade, T.U. and I.K. Ugwa. MusAfrica. 14:11-17(2000).

8. Esekhade T.U., Mesike C.S., Idoko S.O. and Okore I.K. African Journal of Agricultural Research. 9,37: 2834 - 2840(2014). www.academicjournals.org/AJAR

9. Fakayode S.B., R.O. Babatunde and A. Rasheed. American-Eurasian Journal of Scientific Research. 3,1:33-39(2008).

10. Fresco, L. Cassava in shifting cultivation: a systems approach to agricultural technologydevelopment in Africa. Amsterdam, the Netherlands: Royal Tropical Institute (1986).

11. Haggblade, Steven and Zulu, Ballard. Conservation Farming in Zambia. EPTD.Discussion Paper No. 108. Washington, D.C. International Food Policy Research Institute (2003).

12. Idoko, S.O., J.R. Orimoloye, F.O. Uzu, V.I. Orimoloye and I.K. Ugwa. Effects of rock phosphate and indigenous mycorrhizal fungi on cocoyam intercropped with matured rubber plantation in Proceedings of the International Rubber Conference, Vietnam. 30:236-245(2006).

13. Jones, W. O. Manioc in Africa. Food Research Institute. Stanford, CA, USA: Stanford University Press (1959).

14. Kay, R. O. Farm Management, Planning, Control and Implementation. McGraw Hill Book Company, London. p. 154-156 (1981).

15. Masea, A. And R.A. Cramp. Socio-economic aspects of rubber intercropping on acid sand soils in southern Thailand. In: Plant-Soil interaction at low pH In: (R.A. Dote, N.J. Grundson, G.E. Rao and M.E. Robert eds.) Principles and Management Klluwer Pub.Dordresht (1995).

16. Thelma R. Paris. Agricultural systems. 71,1-2:147(2002). Available at http://sciencedirect.com/science?-os=article

17. Willey, R.W. Field Crop Abstract. 32:1-10(1979).

18. Yunusa, I.A.M. Journal of Agric. Science Camp. 112:1-8(1989).

19. Zainol, E.A., A.W. Mahmud and M.N. Sudin. Natural Rubber Research. 8920:124136(1993). 